\title{
PENGUATAN ORIENTASI KEWIRAUSAHAAN MASYARAKAT PENGRAJIN KRUPUK IKAN DI DESA BATAKAN, KECAMATAN PENYIPATAN, KABUPATEN TANAH LAUT
}

\author{
Sampurnawati $^{1}$,Titien Agustina ${ }^{2 *}$, Dodik Jatmika ${ }^{3}$ \\ Asnawi $^{4}$, Muhammad Jahri ${ }^{5}$, TA Hariyono ${ }^{6}$, Muhammad Nurdin ${ }^{6}$, Rezti ${ }^{7}$, \\ Muhammad Ikhwan Nugraha ${ }^{8}$, Muhammad Darwis Meyandie Nasution', Sri Suryani ${ }^{10}$ \\ Alfiannor $^{11}$, Nor Anisa ${ }^{12}$, Santi Nirmala Sari ${ }^{13}$, Maulana ${ }^{14}$, Aini ${ }^{15}$, Yunik Rusmawati ${ }^{16}$ \\ Putri Trisnawati $^{17}$, Nadila ${ }^{18}$, Pitasari $^{19}$, Safitriyani ${ }^{20}$, Muhammad Auliannor ${ }^{21}$ \\ 1,2,3,4,5,6,7,8,9,10,11,12,13,14,15,16,17,18,19,20,21 STIMI Banjarmasin \\ *Email: titienagustina9@gmail.com
}

\begin{abstract}
ABSTRAK
Kegiatan pengabdian kepada masyarakat ini bertujuan dalam rangka melaksanakan salah satu tridharma perguruan tinggi. Kegiatan ini mengambil objek kelompok usaha yang ada di desa dengan melibatkan masyarakat sekitar agar terjadi interaksi dan kolaborasi yang baik. Selain itu juga dengan melakukan belajar bersama lewat metode penyuluhan, FGD dan praktek bersama diharapkan akan dapat mengembangkan potensi kewirausahaan yang sudah ada dan dimiliki sebagian masyarakat. Selain itu bagi anggota masyarakat yang belum terbuka pikiran dan mindsetnya diharapkan akan dapat menumbuhkan dan mengembangkan potensi yang ada di dalam diri. Bagi anggota masyarakat yang sudah memiliki potensi berwirausaha diharapkan akan dapat memperkuat kemampuan berwirausahanya yang sudah ada selama ini. Melalui orientasi kewirausahaan yang terbangun dan berkembang di lingkungan rumah tangga dan makin meluas ke lingkup desa dan lainnya diharapkan akan dapat meningkatkan kesejahteraan masyarakat yang lebih besar lewat kemampuan menggali potensi diri dan desa/lingkungan dalam merubah dan menambah nilai social serta nilai ekonomi yang dapat dihasilkan.
\end{abstract}

Kata kunci: pengabdian kepada masyarakat, pemberdayaan, orientasi kewirausahaan, pengrajin krupuk ikan.

\section{STRENGTHENING THE COMMUNITY ENTREPRENEURSHIP ORIENTATION OF FISH CRUPUK MANUFACTURERS IN BATAKAN VILLAGE, PENYIPATAN SUB-DISTRICT, TANAH LAUT DISTRICT}

\begin{abstract}
This community service activity aims to carry out one of the higher education tri dharmas. This activity takes the object of business groups in the village by involving the surrounding community so that good interaction and collaboration occurs. Through joint learning activities through empowerment methods, counseling, FGDs and collective practice, it is hoped that this will be able to develop the entrepreneurial potential that already exists in some communities. Then for community members who have not yet opened their minds and mindsets, it is hoped that they will be able to grow and develop the potential that is within them selves. It is hoped that members of society who already have entrepreneurial potential will be able to strengthen their entrepreneurial abilities so far. Through an entrepreneurial orientation that is built and developed in the household environment and increasingly extends to the scope of villages and others, it is hoped that it will be able to improve the greater welfare of the community through the ability to explore the potential of themselves and the village / environment in changing and adding to the social and economic values that can be generated. One of them is being able to take advantage of the potential of the village environment to become of high economic value, such as making fish crackers from the village potential.
\end{abstract}

Keyword: community service, empowerment, entrepreneurial orientation, fish cracker craftsmen. 


\section{PENDAHULUAN}

Sebagai negara bahari dan kepulauan terbesar di dunia, Indonesia memiliki berbagai macam ekosistem pesisir dan laut diantaranya sumberdaya perikanan. Meskipun potensi dan pemanfaatan sumberdaya perikanan di perairan tawar, payau maupun laut relatif tinggi, akan tetapi makan ikan belum menjadi budaya di sebagian besar wilayah Indonesia (Djunaidah, 2017). Oleh karena itu guna menggelorakan masyarakat makan ikan, lalu sampai dilakukan suatu gerakan dan kampanye atau promosi gizi (Prameswari, 2018) dari makan ikan dimana-mana dengan berbagai cara dan kesempatan yang tidak pernah berhenti.

Karena mengkonsumsi ikan akan memberikan nurtisi dan gizi yang tinggi pada perkembangan tumbuh kembang fisik dan juga kecerdasan seseorang (Fuada et al., 2018). Bahkan dengan gizi yang cukup dan terpenuhi, bisa mencegah stanting yaitu terhambatnya tumbuh kembang manusia sehingga tidak maksimal. Akibatnya pertumbuhan badan menjadi terhambat dan tidak banyak pertambahan tinggi badan sehingga menjadi rendah atau pendek. Bahkan kadang sampai berakibat pada pertumbuhan otak atau kecerdasan yang juga terganggu.

Padahal Indonesia merupakan Negara yang sangat kaya dengan lingkungan alam, sumber daya air dan laut yang melimpah. Sungai dan laut bahkan pegunungan pun memberikan sumber daya alam yang sangat besar untuk kesejahteraan masyarakatnya, namun masih belum diolah dan diberdayakan secara maksimal. Untuk itu perlu peran serta kaum intelektual dari perguruan tinggi untuk membantu pemerintah dalam membangun kesadaran masyarakat akan potensi yang luar biasa dalam dirinya (Kadiyono, 2014) maupun lingkungannya. Agar mereka mampu dan mau membangun lingkungannya dan memanfaatkannya untuk sebesar-besar kemakmuran kehidupannya bersama keluarga dan masyarakat sekitarnya. Apalagi bisa sampai mengimpor hasil sumber daya alam dan lingkungannya ke luar negeri. Tentu keinginan ini memerlukan sumber daya manusia (SDM) yang berdaya dan memiliki kesadaran akan potensi serta kekayaan lingkungannya ini. Untuk membuat masyarakat berdaya, tentu diperlukan pendidikan, namun tidak semua penduduk, apalagi di daerah pesisir dan pinggiran maupun pegunungan yang terjangkau pendidikan formal yang baik dan bagus. Sehingga diperlukan peran seerta pihak lainnya, salah satunya perguruan tinggi untuk bisa memberikan pencerahan dan pemberdayaan pada masyarakat pesisir dalam kemampuannya melihat, menangkap dan mengolah potensi lingkungannya yang makin bermanfaat dan mensejahterakan kehidupannya.

Batakan sebagai sebuah desa yang berada persis dipesisir laut, memiliki potensi alam yang luar biasa. Salah satunya adalah hasil ikan laut yang melimpah. Salah satunya adalah ikan laut yang bisa dimanfaatkan secara maksimal. Ikan sebagai bahan pangan di Indonesia memiliki beberapa keunggulan, diantaranya: sebagai sumber nutrisi esensial, white meat, bersifat universal, harga relatif murah, proses produksi relatif singkat, serta suppy lokal. Tingkat konsumsi ikan di Indonesia relatif rendah (Djunaidah, 2017) dibandingkan dengan potensi sumber daya perikanan yang dimiliki. Sehingga masih terdapat kualitas pertumbuhan manusia Indonesia yang masih rendah. Masih banyak kasus stanting pada anak-anak Indonesia. Padahal solusinya ada pada nutrisi dan gizi yang bersumber dari konsumsi ikan yang tinggi.

Salah satu budaya yang harus dibangun kembali dan dikuatkan adalah dalam hal mengkonsumsi ikan bagi masyarakat. Selama ini dalam budaya masyarakat ada kebiasaan yang melarang memakan ikan yang banyak, karena akan cacingan. Pameo inilah yang masih sangat kuat tertanan dalam kebiasaan dan budaya masyarakat Indonesia, khususnya di Kalimantan Selatan bahwa bila memakan ikan terlalu banyak akan mengakibatkan cacingan. Sehingga sangat dihindarkan memakan ikan yang banyak, mengkonsumsi ikan sekedarnya saja, karena yang membuat kenyang perut itu berasal dari karbohidrat yaitu nasi. Sehingga menu makan keluarga lebih banyak mengkonsumsi nasi sebagai sumber karbohodrat yang membuat perut cepat kenyang dan tubuh menjadi kuat, dibandingkan mengkonsumsi ikan yang banyak. Karena akan menyebabkan cacingan.

Kebiasaan memakan ikan yang banyak sangat dihindari dan dijauhkan oleh orang tua kepada anak-anak dahulu harus mulai dihilangkan dengan melalui promosi atau kampanye makan ikan (Prameswari, 2018) pada anak-anak. Karena ini akan meningkatkan kualitas Sumber Daya Manusia (SDM) Indonesia ke depan. Melalui kampanye atau promosi nilai dan nutrisi ikan yang sangat tinggi bagi tumbuh kembang manusia diharapkan akan dapat menghapus pameo yang ada selama ini. Memang pada jenis ikan tertentu memiliki struktur tulang yang banyak, sehingga bisa menjadi salah 
satu cara orang tua untuk menjauhkan kebiasaan anak suka makan ikan. Agar ikan bisa menjadi pilihan konsumsi masyarakat, maka ada baiknya ikan yang melimpah ini dibuat dengan berbagai macam hasil olahan lainnya yang tidak mengurangi nilai gizi. Diantaranya adalah dengan membuat ikan menjadi krupuk ikan, namun komposisi ikannya harus proporsional agar gizi dari ikan dan kandungan nutrisi yang maksimal bisa didapat dari memakan krupuk ikan ini.

Desa Batakan memiliki banyak pengrajin krupuk, karena memang lokasinya persis merupakan pesisir pantai dan mata pencaharian penduduk yang utama juga adalah sebagai petani. Tentu banyak hasil laut ini yang tidak selalu habis terjual pada saat nelayan dating dari laut. Beberapa ikan sisa pilihan yang dibeli oleh pengumpul ikan akan menjadi sumber daya lingkungan yang harus bisa dimanfaatkan lagi dengan berbagai cara agar masih bisa memberikan nilai ekonomis pada masyarakat. Krupuk menjadi salah satu pilihan untuk itu.

Melalui kegiatan pengabdian kepada masyarakat yang dilaksanakan dosen, tenaga kependidikan dan mahasiswa STIMI Banjarmasin kepada masyarakat dipesisir laut Desa Batakan Kabupaten Tanah Laut ini diharapkan akan dapat memberikan pencerahan dan masukan-masukan yang akan memperkaya sumber pendapatan masyarakat sehingga meningkatkan nilai lingkungan dan juga menjadikan masyarakat terbuka terhadap perkembangan dunia. Lewat pemasaran produk yang bagus kemasannya, memiliki kualitas produk yang bersaing dan mampu mengelola lingkungan sehingga menjadi produk yang bernilai gizi tinggi dan bernilai ekonomis tinggi pula lewat berbagai olahan dari bahan ikan laut, diantaranya udang yang menjadi objek dalam pembuatan krupuk kali ini.

\section{KAJIAN TEORITIS}

\section{Keunggulan Ikan}

Keunggulan ikan sebagai sumber pangan yang sehat dan menyehatkan tidak diragukan lagi. Sebagai salah satu sumber protein hewani bagi pemenuhan kebutuhan masyarakat Indonesia, ikan memiliki berbagai keunggulan (Djunaidah, 2017). Sumber nutrisi esensial. Sebagai bahan pangan, Ikan tidak hanya sebagai sumber protein, ikan juga sebagai sumber lemak, vitamin, dan mineral yang sangat baik dan prospektif. Data Susenas BPS menunjukkan bahwa sumbangan protein ikan terhadap konsumsi protein hewani masyarakat Indonesia mencapai 57\% (Saefudin, 2015). Kelebihan ikan sebagai salah satu sumber protein hewani adalah karena kuantitasnya yang mengandung protein dalam kisaran 15-24\% serta kualitasnya yang ditunjukkan dengan kelengkapan asam amino esensialnya serta tingkat kecernaaanya yang mencapai angka 95\% (Rahayu dkk, 1992). Selain itu, ikan juga mengandung asam lemak omega-3 yang sangat penting bagi perkembangan jaringan otak dan mencegah terjadinya penyakit jantung, stroke dan darah tinggi serta mengurangi resiko beberapa jenis penyakit lainnya. Begitu pula peneliti lain,

Leaf dan Weber (1988) dalam (Djunaidah, 2017) melaporkan bahwa mengkonsumsi ikan mampu melindungi dari serangan penyakit jantung diduga karena faktor keberadan asam lemak omega 3 dalam ikan. Asam lemak tersebut memiliki peran penting dalam metabolism seperti menghambat platelet aggregation dan menurunkan level dari serum triglyceride yang akan memegang peranan dalam pencegahan penyakit jantung. Penelitian Kremhout et.al (1985) dalam (Djunaidah, 2017) juga mengindikasikan adanya perbandingan terbalik antara jumlah konsumsi ikan dengan kejadian kematian karena serangan jantung. Menurut (Heruwati, 2002) bahwa ikan diakui sebagai fungsional food yang memiliki arti penting bagi kesehatan karena mengandung asam lemak tidak jenuh berantai panjang (terutama yang tergolong asam lemak omega 3). Dari hasil penelitiannya terhadap tiga kelompok sampel yang berkebangsaan Finlandia, Italia dan Belanda, Oomen dkk (2005) melaporkan bahwa terdapat hubungan antara konsumsi ikan dengan kematian akibat serangan jantung. Mereka juga menyatakan bahwa asam lemak omega 3 yang ada terkandung dalam ikan yang dikonsumsi berperan secara nyata.

\section{Pemberdayaan Masyarakat}

Menurut Puspensos, pemberdayaan pada hakekatnya adalah upaya pemberian daya atau peningkatankeberdayaan. Pemberdayaan masyarakat dapat diartikan sebagai upaya untuk memandirikanmasyarakat agar mampu berpartisipasi aktif dalam segala aspek pembangunan. Kemandirian bukan berarti mampu hidup sendiri, tetapi mandiri dalam pengambilan keputusan, yaitu memiliki kemampuan untuk memilih dan keberanian menolak segala bentuk bantuan dan atau 
kerjasama yang tidak menguntungkan. Dalam wikipedia dapar diartikan bahwa pemberdayaan masyarakat adalah proses pembangunan dimana masyarakat berinisiatif untuk memulai proses kegiatan sosial untuk memperbaiki situasi dan kondisi diri sendiri. Dimana masyarakat sendirilah yang menjadi pemeran utama dalam berlangsungnya kegiatan ini. Oleh karena itu, pemberdayaan sosial tidak akan berjalan tanpa adanya partisipasi masyarakat.

Optimalisasi segenap sumber daya dan potensi yang dimiliki sangat dipentingkan dalam hal ini. Ketidaktahuan dan atau ketidakmampuan segenap elemen penyelenggara pembangunan atas potensi yang ada, menjadi salah satu titik lemah laju pembangunan. Pemerintah daerah pada umumnya dan masyarakat pada khususnya dipandang penting untuk menggali dan mengkaji setiap potensi yang dimilikinya. Ketidakmampuan dan ketidaktahuan masyarakat mengakibatkan produktivitas mereka rendah. Kemampuan masyarakat yang dapat dikembangkan tentunya banyak sekali seperti kemampuan untuk berusaha, kemampuan untuk mencari informasi, kemampuan untuk mengelola kegiatan, kemampuan dalam pertanian dan masih banyak lagi sesuai dengan kebutuhan atau permasalahan yang dihadapi oleh masyarakat. Perilaku masyarakat yang perlu diubah tentunya perilaku yang merugikan masyarakat atau yang menghambat peningkatan kesejahteraan masyarakat.

Pemberdayaan masyarakat bukan membuat masyarakat menjadi makin tergantung pada berbagai program pemberian (charity) dari Pemerintah. Dengan demikian tujuan akhirnya adalah memandirikan masyarakat, memampukan, dan membangun kemampuan untuk memajukan diri ke arah kehidupan yang lebih baik secara berkesinambungan. Pemberday aan dimaksudkan juga untuk menciptakan keberdayaan masyarakat agar mereka dapat berpartisipasi dalam pembangunan yang berpusat pada rakyat (people-centered development). Pemberdayaan tidak hanya menyangkut pendanaan, tetapi juga peningkatan kemampuan sumber daya manusia (SDM) dan kelembagaan.

Wikipedia (2020) menyebutkan ada 3 tujuan utama dalam pemberdayaan masyarakat yaitu mengembangkan kemampuan masyarakat, mengubah perilaku masyarakat, dan mengorganisir diri masyarakat. Kegiatan pemberdayaan tidak hanya menyangkut pendanaan tetapi juga peningkatan kemampuan sumber daya manusia (SDM) dan kelembagaan. Perguruan Tinggi memiliki tugas untuk terlibat langsung atau tidak langsung dalam memberdaya kan lingkungan maupun masyarakat dimanapun agar keberadaan Perguruan Tinggi tidak menjadi "menara gading" yang hanya bisa berteori namun tidak bisa mengimplementasikan teori-teori temuannya kepada kehidupan yang sesungguhnya.

Oleh karena itu melalui salah satu tridharma yang menjadi tugas dosen dan perguruan tinggi, Tim pengabdian masyarakat dari STIMI Banjarmasin melakukan upaya turun ke masyarakat pesisir di Desa Batakan yang memiliki kekayaan potensi laut yang luar biasa. Pemberdayaan dilakukan dalam bentuk kegiatan penyuluhan dan praktek keterampilan berproduksi sehingga membuka wawasan dan cakrawala berpikir masyarakat akan peluang usaha yang bisa dimasuki dengan memanfaatkan potensi lingkungan sehingga bernilai ekonomi tinggi. Hasil penelitian (Hadiyanti, 2008) menyebut bahwa pemberdayaan masyarakat bertujuan untuk meningkatkan keterampilan dan produktivitas masyarakat sehingga mereka menjadi mandiri yang pada akhirnya meningkatkan taraf hidup masyarakat.

Proses pemberdayaan masyarakat bertitik tolak untuk memandirikan masyarakat agar dapat meningkatkan taraf hidupnya sendiri dengan menggunakan dan mengakses sumber daya setempat sebaik mungkin. Sasaran utama pemberdayaan masyarakat adalah masyarakat miskin (bisa dalam arti sempit atau pun dalam arti luas). Dalam prosesnya perlu diperhatikan bahwa perempuan akan terlibat secara aktif. Proses pemberdayaan masyarakat didampingi oleh suatu tim fasilitator yang bersifat multidisiplin. Tim pemberdayaan masyarakat sebaiknya terdiri dari laki-laki dan perempuan. Peran utama tim pemberdayaan masyarakat adalah mendampingi masyarakat dalam melaksanakan proses pemberdayaan. Peran tim pemberdayaan masyarakat pada awal proses sangat aktif tetapi akan berkurang selama proses berjalan sampai masyarakat sudah mampu melanjutkan kegiatannya secara mandiri.

Pemberdayaan menempatkan masyarakat sebagai subyek untuk mengenali permasalahan, ikut dalam perencanaan program akan menghasilkan kemandirian yang tinggi (Mubyarto,1984; Sajogyo, 1982). Menurut Syahyuti (2007) pemberdayaan berarti mempersiapkan masyarakat untuk memperkuat diri dan kelompok mereka dalam berbagai hal, mulai dari sosial kelembagaan, kepemimpinan, sosial ekonomi dan politik dengan menggunakan basis kebudayaan mereka sendiri (Darwis, 2013). 
Oleh karena tujuan utama pemberdayaan adalah memampukan dan memandirikan masyarakat, baik secara social maupun ekonomi, maka diperlukan suatu taktik dan strategi agar masyarakat mau mengikuti proses yang dilaksanakan. Dimana inti dari pemberdayaan adalah memampukan dan memandirikan masyarakat baik secara social, ekonomi juga pola piker dan sikapnya, maka yang paling mudah ditempuh adalah dengan melakukan pedekatan bersama-sama kepada masyarakat yang dituju dan tim harus bisa memindahkan nilai, pengetahuan, keyakinan, kemampuan bahkan keterampilan yang ingin dipindahkan dan dimiliki oleh masyarakat itu melalui proses belajar bersama. Banyak cara untuk melakukan proses belajar social ini, diantaranya dengan ceramah, penyuluhan, praktek melakukan atau membuat sesuatu bersama dan dalam bimbingan, focus group discussion (FGD), musyawarah, dan lain-lain. Intinya ada proses yang terjadi secara mengalir dari tim atau instuktur atau fasilitator atas hal-hal yang ingin ditanamkan dan diberikan kepada masyarakat melalui berbagai cara dan pendekatan yang sifatnya sangat situasional. Karena pada masyarakat yang berbeda, kadang tidak bisa disamakan cara dan strategi maupun pendekatan yang dilakukan agar komunikasi dan hubungan bisa menjadi akrab, dekat, dan nilai-nilai yang ingin dipindahkan bisa berjalan dengan lancar dan menyenangkan.

\section{Orientasi Kewirausahaan}

Dalam kegiatan pengabdian masyarakat ini Tim mengambil objek pada masyarakat pesisir pantai Desa Batakan Kabupaten Tanah Laut yang umumnya mata pencaharian utamanya adalah sebagai nelayan. Selain itu juga bertani, apabila tidak pergi melaut mencari ikan bagi kaum lakilakinya. Sementara bagi kaum perempuannya dan ibu-ibu rumah tangga selain mengolah ikan yang dibawa suaminya, juga pergi membantu ke sawah. Setelah itu umumnya banyak berdiam diri di rumah atau melakukan kegiatan pengajian. Kalaupun mempunyai minat dalam berdagang, mereka melakukan kegiatan berdagang dengan membawa ikan tangkapan suaminya atau menjadi pengumpul dari sesame nelayan dan membawanya keluar desa untuk dijual. Seperti ke ibu kota kecamatan, ibu kota kabupaten dan sampai ke Banjarmasin.

Karena kehidupan mereka berjalan dan mengalir mengikuti kebutuhan dan kondisi lingkungannya sehingga umumnya tidak mempunyai inisiatif yang lebih jauh dalam melihat, membaca, dan memanfaatkan potensi desa dan lingkungan yang ada untuk berwirausaha lebih jauh. Memanfaatkan waktu yang tersisa setelah pergi berjualan hasil laut. Atau memanfaatkan sisa ikan tangkapan yang kurang baik atau tidak laku dijual melalui proses pengolahan yang bernilai ekonomi lebih tinggi lagi. Umumnya hal ini belum terpikirkan dan tidak terjangkau dalam pikiran mereka. Kalaupun sudah ada pemikiran itu, namun dengan keterbatasan kemampuan, pemikiran, jaringan dan keterampilan yang dimiliki, membuat mereka merasa tidak mampu berbuat lebih banyak lagi dengan potensi lingkungan yang ada ini.

Pemberian orientasi kewirausahaan melalui berbagai cara pemberdayaan yang dilakukan, diharapkan bisa menumbuhkan kemampuan berpikir, kemampuan berdaya dan mandiri, serta kemampuan bersaing yang lebih tinggi lagi di dalam mengolah dan memanfaatkan lingkungannya untuk peningkatkan kesejahteraan kehidupannya. Pemberian materi terkait orientasi kewirausahaan bisa mendorong dan menumbuhkan kesadaran potensi diri dan lingkungannya (Kadiyono, 2014) sehingga mampu memberdayakan diri dan lingkungannya lebih tinggi lagi. Karena banyak potensi dalam dirinya sebagai manusia yang bisa digali dan mampu dikembangkan semaksimalnya untuk mengolah alam dan lingkungan sekitarnya. Hasil penelitian (Diandra, 2016) menunjukkan bahwa dengan peningkatan orientasi kewirausahaan akan dapat meningakatkan pengetahuan kewirausahaan, kemampuan kewirausahaan, serta mental kewirausahaan. Diharapkan pada tahap berikutnya akan bisa memberikan dampak pada peningkatan kemampuan olah pikir, olah sikap dan olah perilaku yang berubah dalam meningkatkan kemampuan mensejahterakan kehidupannya pribadi dan keluarga bahkan juga lingkungannya.

\section{METODE KEGIATAN}

Kegiatan pengabdian masyarakat ini dilaksanakan dengan 2 (dua) metode yaitu pemberian penyuluhan terkait upaya membangun, menanamkan kembali dan memperkuat orientasi 
kewirausahaan masyarakat desa Batakan dalam melihat peluang dan kesempatan untuk meningkatkan nilai ekonomi lingkungan melalui kegiatan kedua, yaitu praktek pembuatan krupuk ikan dan udang.

Pada kegiatan pertama, yaitu penyuluhan menggunakan metode ceramah dan Focus Group Discussion (FGD) sehingga terbangun suasana menyenangkan dan bersama dengan itu disampaikan materi terkait pembangunan pola pikir (mindset) dan kesadaran akan kekayaan alam lingkungannya yang melimpah sehingga perlu diberdayakan untuk menjadi sumber kehidupan yang sejahtera bagi masyarakatnya. Penyuluhan dilakukan dengan komunikasi dua arah sehingga apa yang dirasakan dan diaalami langsung masyarakat dalam kehidupannya menangkap peluang dan kesempatan yang ada di lingkungannya bisa diberikan pencerahan dan dicarikan solusi untuk pengembangan lebih lanjut.

Melalui kegiatan kedua berupa praktek mengolah atau memproduksi pembuatan krupuk ikan laut dan udang yang enak dan renyah. Kemudian juga diberikan penyuluhan terkait manajemen pemasaran melalui kemasan yang menarik serta manajemen administrasi usaha melalui pendaftaran untuk mendapatkan P-IRT serta mengurus label Halal. Karena untuk mereka bisa memasukkan produk ke retail besar, tentu diperlukan kelengkapan administrasi seperti P-IRT dan kadang-kadang juga label Halal sehingga makin memperluas jaringan pemasaran dan penyebaran produk di mana saja, tanpa dibatasi oleh kemampuan jangkauan sendiri karena akan dilakukan dengan system jaringan.

\section{PEMBAHASAN}

Batakan adalah daerah pesisir yang memiliki sumber daya alam dan laut yang luar biasa. Tetapi sampai saat ini masih belum mampu menunjukkan eksistensinya ke dunia luar, paling tidak di lingkungan Kalimantan Selatan sebagai daerah penghasil ikan dan berbagai olahan produk dari ikan laut yang menjadi kekayaan desanya. Melihat permasalahan dan peluang yang sangat bisa dikembangkan menjadi bernilai ekonomis tinggi, Tim dosen, tenaga kependidikan dan mahasiswa dari Sekolah Tinggi Ilmu Manajemen Indonesia (STIMI) Banjarmasin tertarik untuk turut membangun dengan memberdayakan kekayaan potensi desa dan potensi sumber daya manusianya untuk mampu masuk dalam persaingan yang ada. Agar kehidupan mereka bisa lebih meningkat lagi.

Melalui penyuluhan yang berbentuk ceramah dan diskusi dalam rangka membuka wawasan, pemikiran, dan menggali ide-ide masyarakat terhadap potensi yang ada disekeliling mereka, tim melakukan olah piker dan membuka cakrawala mereka untuk mampu melihat potensi dan peluang yang ada disekeliling mereka. Dengan tanggapan yang cukup antusias dari masyarakat lewat dialog yang dibangun dengan kekeluargaan dan komunikasi yang komunkatif, sangat kental kedaerahan, membuat peserta menjadi nyaman dan bersemangat dalam mendengarkan uraian-uraian yang disampaikan oleh tim secara bergantian dan saling melengkapi.

Dalam diskusi yang cukup panjang masyarakat bisa menangkap apa yang disampaikan dan diinginkan tim agar mereka mampu melihat potensi yang ada disekelilingnya. Menjadikan berbagai sumber daya yang dimiliki disekitar tempat tinggal mereka bagaimana menjadi bernilai ekonomis. Kemudian dilanjutkan dengan materi tentang pentingnya produk yang sudah dihasilkan itu dikemas yang cantik dan menarik. Kemudian dilengkapi dengan tata cara dan teknis pengurusan P-IRT di kecamatan, peluang mendapatkan kredit mikro kecil yang lunak serta kemungkinan pengurusan label halal. Selain itu juga disampaikan teknis pemasaran melalui jaringan dengan memanfaatkan media komunikasi yang dimiliki yaitu smartphone untuk bisa berjualan secara online. Mencari jaringan, dan juga mengembangkan pasar sampai lokasi yang tidak terbatas melalui kemampuan jangkauan internet yang ada. Dari sini akan membuka peluang baru kepada masyarakat yang lain yang tidak melaut, tidak berproduksi, dengan mengambil peran menjadi pengusaha jasa pengiriman produk dari desa ke luar desa, bahkan ke luar kabupaten, provinsi, dan bahkan luar negeri.

Hal-hal seperti itu makin membuka wawasan dan pengetahuan masyarakat desa terhadap kemungkinan peluang usaha yang bisa dikembangkan dan digarap sehingga nilai ekonomi lingkungan juga akan makin meningkat. Belum dengan produk yang bisa dihasilkan dari hasil laut tersebut. Melalui olahan yang dilakukan sendiri oleh nelayan dan keluarganya di lingkungan desa, tentu akan bisa meningkatkan nilai tambah hasil alam daripada hanya dijual dalam bentuk mentah. 
BAKTI BANUA : Jurnal Pengabdian Kepada Masyarakat

Volume 1 No. 1 Mei 2020

https://ejurnal.stimi-bjm.ac.id/index.php/BBJM/

Berikut ini gambar kegiatan dalam praktek pengolahan krupuk:

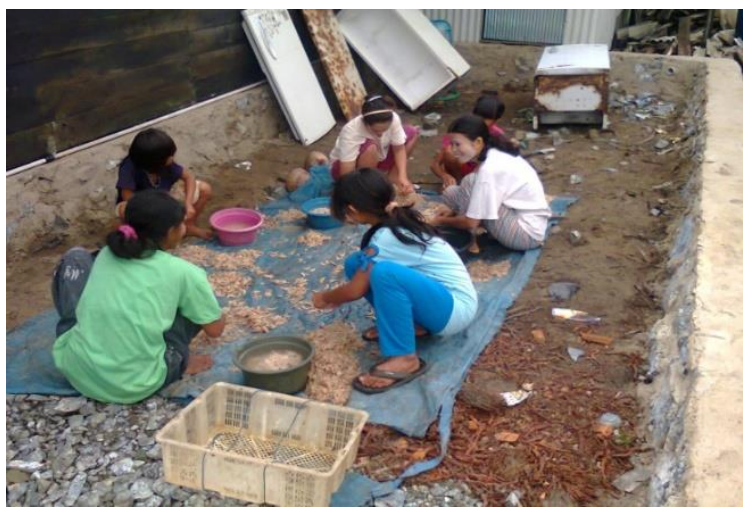

Gambar 1 Ibu-ibu Penyiang Udang

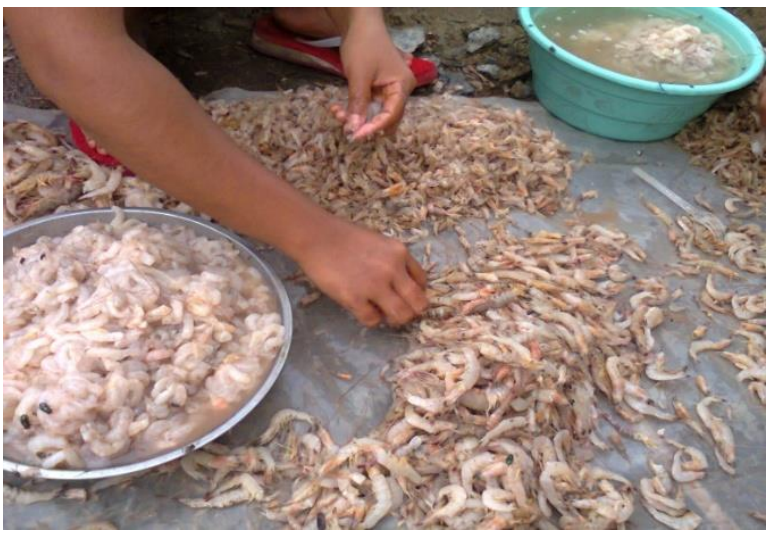

Gambar 3 Proses membuang kulit udang

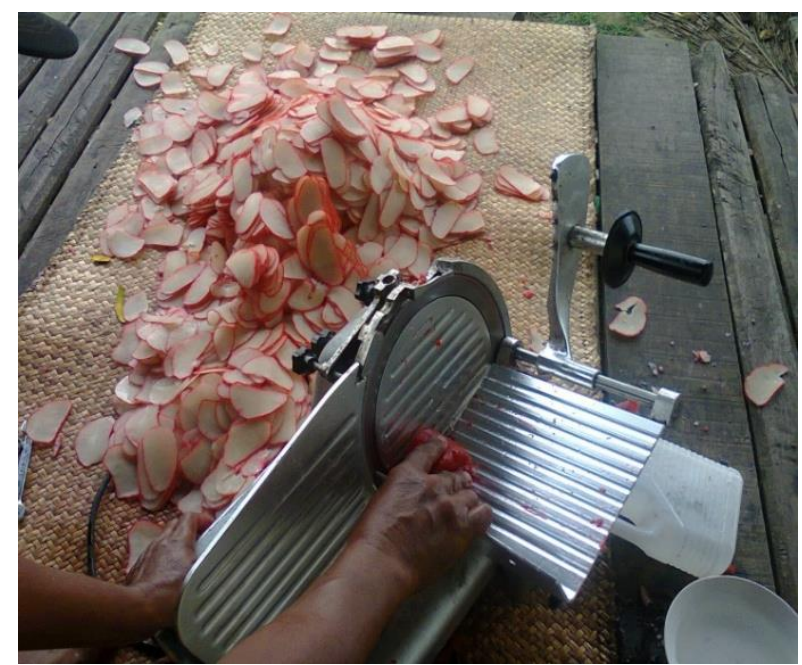

Gambar 5

Bahan olahan krupuk dipotong-potong

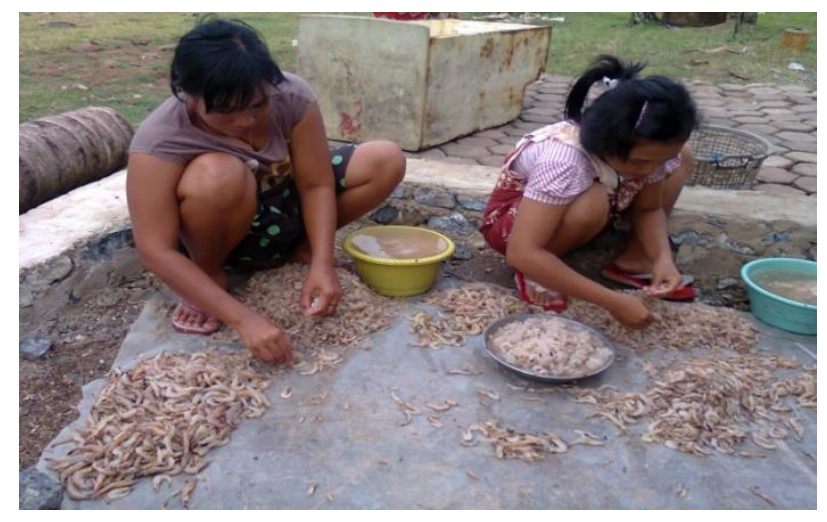

Gambar 2 Kulit udang dibuang dan dibersihkan

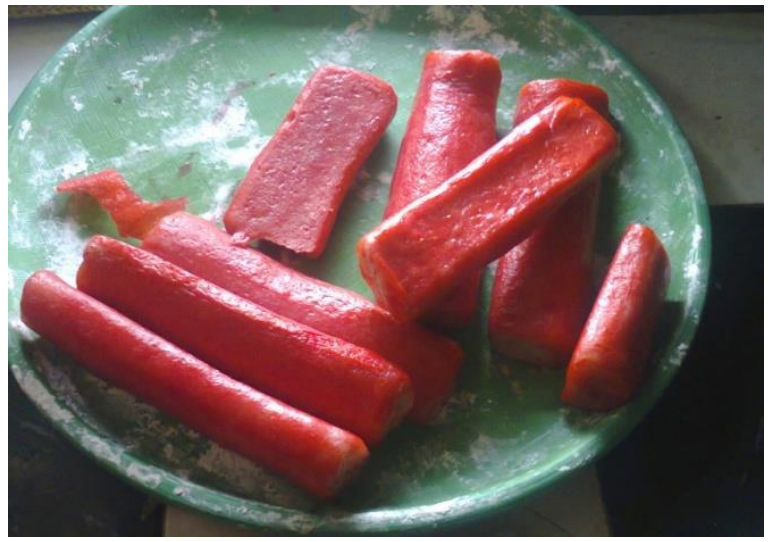

Gambar 4 Bahan olahan yg sudah dikukus

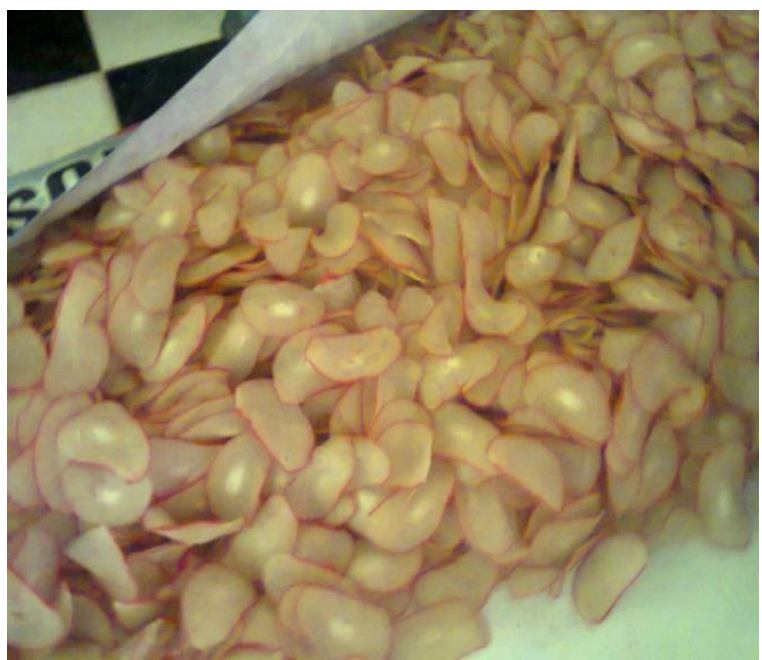

Gambar 6

Krupuk yang dijemur dan siap dikemas

Langkah-langkah dalam pembuatan bahan krupuk memerlukan ketelatenan namun tidak sulit. Melalui campuran bahan selain ikan atau udang, ditambah dengan tepung terigu, tepung sagu atau tepung kanji, garam, bawang putih, ketumbar dan bahan penyedap bila suka. 
Diolen menjadi satu hingga dapat dibentuk menjadi bulatan panjang (gambar 4) lalu dikukus. Kemudian didinginkan setelah dingin siap untuk dipotong-potong (gambar 5) dengan mesin pemotong manual yang dapat dikembangkan sendiri. Hasil pemotongan lalu dijemur pada panas matahari yang cukup hingga kering yang bagus. Bila sudah kering maka siap untuk ditimbang, dikemas dan dipasarkan.

\section{PENUTUP}

Untuk merubah pola pikir, mindset dan kebiasaan masyarakat yang sudah turun temurun, kemudian menjadikan mereka terbuka terhadap kondisi lingkungan sehingga mampu membaca peluang dan memanfaatkan sumber daya lingkungan tempat tinggal mereka, kadang diperlukan orang luar guna memotivasi, menumbuhkan dan memberdayakan. Perguruan Tinggi memiliki tugas dalam tridharma, selain melakukan pendidikan dan pengajaran, serta penelitian, maka juga diperlukan kegiatan pengabdian kepada masyarakat yang menjadi wadah atau tempat untuk implementasi dari hasil kegiatan di kampus.

STIMI Banjarmasin yang memiliki bidang focus pada manajemen, dengan konsentrasi yang bisa dikembangkan, dapat memberikan kontribusinya pada masyarakat sesuai dengan kemampuan dan keahlian masing-masing. Melalui pemberian penyuluhan kepada masyarakat diharapkan dapat membuka pikiran dan merubah sikap mental dan sikap perilaku masyarakat dalam melihat lingkungan dan mampu memberdayakannya untuk semaksimal kesejahteraan mereka sendiri. Melalui kegiatan penyuluhan yang dilakukan di Desa Batakan, Kecamatan Penyipatan, Kabupaten Tanah Laut beberapa waktu yang lalu ini, diharapkan bisa membuka wawasan dan gagasan-gagasan segar dari masyarakat untuk mampu mengambil kesempatan yang ada di lingkungannya sendiri. Sebelum pihak luar yang dating sebagai investor dan menggarap lingkungan mereka sehingga mereka tidak bisa berperan maksimal atau bahkan tersisih dari lingkungan kehidupannya selama turun temurun.

Pemberian praktek dan keterampilan dalam mengolah potensi yang ada menjadi salah satu cara agar masyarakat mampu melihat peluang bisnis. Mampu mengembangkannya hingga membawa manfaat dan nilai ekonomis yang tinggi untuk kehidupan keluarga dan masyarakatnya ke depan.

Krupuk merupakan penganan pendamping nasi bagi Orang Indonesia. Krupuk ikan menjadi salah satu cara untuk membuat masyarakat gemar makan ikan. Selain itu bagi nelayan pesisir, krupuk bisa dibuat dari ikan-ikan sisa pilihan yang dijual dalam bentuk mentah, sehingga sisa ikan pilihan yang tidak dibeli pedagang atau pengumpul, akan bisa bermanfaat plus ketika diolah lagi menjadi bahan olahan. Salah satunya adalah krupuk yang bisa menambah nilai gizi masyarakat serta meningkatkan nilai ekonomi keluarga serta lingkungan.

\section{UCAPAN TERIMA KASIH}

Ucapan terima kasih Tim Pengabdian kepada Masyarakat STIMI Banjarmasin kepada Ibu Misna Yanti, Ketua Kelompok Pinus Permai Desa Batakan beserta anggota dan masyarakat sekitar di Jl. Pariwisata RT.16 atas kesediaannya untuk berbagi ilmu dan menyediakan tempat kegiatan. Terima kasih juga kepada Pimpinan STIMI Banjarmasin dan tim yang telah melakukan kegiatan ini untuk memberdayakan masyarakat pesisir. Semoga bermanfaat.

\section{DAFTAR PUSTAKA}

Darwis, V. (2013). Pelaksanaan dan manfaat kegiatan pemberdayaan masyarakat rawan pangan di DKI Jakarta. Sepa, 10(1), 88-96. 
Diandra, D. (2016). Program Pengembangan Kewirausahaan Untuk Menciptakan Pelaku Usaha Sosial Yang Kompetitif. Jurnal.Polban.Ac.Id, 138-146. https://jurnal.polban.ac.id/proceeding/article/view/214

Djunaidah, I. S. (2017). Level of Fish Consumption in Indonesia: Irony in The Nautical Country. Jurnal Penyuluhan Perikanan Dan Kelautan, 11(1), 12-24.

Fuada, N., Muljati, S., Triwinarto, A., Penelitian dan Pengembangan Kesehatan Magelang, B., Penelitian dan Pengembangan Upaya Kesehatan Masyarakat, P., Penelitian dan Pengembangan Kesehatan, B., Kesehatan Kapling Janan, K. R., Tengah, J., \& Kesehatan Jl Percetakan, K. R. (2018). Protein Penduduk Indonesia (the Contribution of Marine Fisheries in Protein Adequacy Indonesian Population). 41(2), 77-88.

Hadiyanti, P. (2008). Strategi Pemberdayaan Masyarakat Melalui Keterampilan Produktif. Perspektif Ilmu Pendidikan, 17(9), 90-99.

Heruwati, E. S. (2002). Pengolahan ikan secara tradisional: Prospek dan peluang pengembangan. Jurnal Litbang Pertanian, 21(3), 92-99.

Kadiyono, A. L. (2014). Efektivitas pengembangan Potensi Diri dan Orientasi Wirausaha Dalam Meningkatkan Sikap Wirausaha. Jurnal Intervensi Psikologi, 6(1), 25-38.

Prameswari, G. N. (2018). Promosi Gizi Terhadap Sikap Gemar Makan Ikan Pada Anak Usia Sekolah. Journal of Health Education, 3(1), 1-6.

https://doi.org/10.15294/jhe.v3i1.18379

Puspensos. Pentingnya Pemberdayaan Sosial masyarakat Desa. Diakses melalui web: https://puspensos.kemsos.go.id/pentingnya-pemberdayaan-sosial-masyarakat-desa-diera-globalisasi. Pada tanggal 16 April 2020

Rahayu, W.P., Slamet, M., Suliantari, dan Srikandi, F. 1992. TEKN OLOGI FERMENTASI PRODUK PERIKANAN Departemen Pendidikan dan Kebudayaan, Direktorat Jenderal Pendidikan Tinggi, Pusat Antar Universitas Pangan dan Gizi, Institut Pertanian Bogor. 140 halaman. 